УДК 792.82:792.026

DOI: $10.31866 / 2616-7646.4 .1 .2021 .236212$

\title{
БАЛЕТНЕ ЛІБРЕТО ЯК ПРЕДМЕТ КОНЦЕПТУАЛЬНОГО АНАЛІЗУ ХОРЕОГРАФІЧНОГО ТВОРУ (НА МАТЕРІАЛІ ТВОРІВ УКРАЇНСЬКИХ КОМПОЗИТОРІВ)
}

\author{
Чепалов Олександр Іванович, \\ доктор мистецтвознавства, професор, \\ Київський національний університет культури і мистецтв, \\ Київ, Україна, \\ https://orcid.org/0000-0002-2033-357X, \\ chepalovstagmail.com
}

\begin{abstract}
Мета статті - з'ясувати закономірності й засоби практичного створення сценарію балетної вистави з позицій драматичної та музично-хореографічної побудови. Методологія. Суміщення емпіричного методу, заснованого на практиці фахового досвіду створення балетних лібрето із загальнонауковими підходами, зокрема аналогії та моделювання, абстрагування та конкретизації, що випливають 3 концептуальних основ засад образнохудожнього втілення сценічного твору. Наукова новизна. У порівнянні з оперною лібретологією загальна теорія й практика балетного лібрето не розроблена; отже, запропоноване дослідження є одним із перших, що претендує на теоретичні узагальнення та відтворює більш сучасний погляд на одну з нагальних проблем створення балетної вистави у наш час. Висновки. У радянському балеті у зв’язку із завданнями ідейності та змістовності драматургії, роль сценарію підвищилася порівняно з балетами минулого. Однак прагнення наблизити сценарій до драматичної п’єси (особливо типове явище для 1930-50-х рр.) давало результати не лише позитивні (в галузі драматургії видовища), а й негативні (порушення законів балетної специфіки, втрата розвиненої танцювальності). Гармонія поєднання сценарної та музично-хореографічної драматургії можлива лише в спектаклях, у яких сценарії створені з урахуванням специфіки музики й хореографії та їхнього органічного злиття. Завдяки розширенню та збагаченню сучасними елементами виражальних засобів хореографії балетні лібрето ставали не просто розширеним описом сценічних подій, а їхнім більш коротким та ємним викладенням, вони давали широкий простір фантазії глядача та когнітивного сприйняття хореографічного тексту. Українські митці орієнтувалися переважно на класичні балетні зразки, звертаючись до вітчизняної та світової літературної класики, сюжетів-легенд, творів історично-патріотичної тематики. Деякі балети створювались до суспільно значущих подій (напр., «Вогонь Еліди» В. Золотухіна до Олімпіади 1980 р. у Москві). Балет В. Бібіка на 2 дії «Гутаперчевий хлопчик» написаний за однойменною повістю Д. Григоровича (зберігся тільки у клавірі). Створення драматургії балетної вистави вимагає значно більших зусиль, ніж в опері; її відрізняють від сценарної форми, апробованої в оперній виставі, монологи, діалоги та прописаний (переважно в ремарках) підтекст.
\end{abstract}

Ключові слова: балетне лібрето; сценарна драматургія балету; балетна музика українських композиторів; композитор Володимир Золотухін; композитор Валентин Бібік. 
БАЛЕТНОЕ ЛИБРЕТТО КАК ПРЕДМЕТ КОНЦЕПТУАЛЬНОГО АНАЛИЗА ХОРЕОГРАФИЧЕСКОГО ПРОИЗВЕДЕНИЯ (НА МАТЕРИАЛЕ ПРОИЗВЕДЕНИЙ УКРАИНСКИХ КОМПОЗИТОРОВ)

\author{
Чепалов Александр Иванович, \\ доктор искусствоведения, профессор, \\ Киевский национальный университет \\ культуры и искусств, \\ Киев, Украина, \\ https://orcid.org/0000-0002-2033-357X, \\ chepalovstagmail.com
}

Цель статьи - выяснить закономерности и средства практического создания сценария балетного спектакля с позиций драматического и музыкально-хореографического построения. Методология. Сочетание эмпирического метода, основанного на практике профессионального опыта создания балетных либретто с общенаучными подходами, в частности аналогии и моделирования, абстрагирования и конкретизации, вытекающих из концептуальных основ засад образно-художественного воплощения сценического произведения. Научная новизна. По сравнению с оперной либретологиею общая теория и практика балетного либретто не разработана; следовательно, представленное исследование является одним из первых, претендующих на теоретические обобщения и воспроизводит более современный взгляд на одну из насущных проблем создания балетного спектакля в наше время. Выводы. В советском балете, в связи с задачами идейности и содержательности драматургии, роль сценария повысилась по сравнению с балетами прошлого. Однако стремление приблизить сценарий к драматической пьесе (особенно типичное явление для 1930-50-х гг.) Давало результаты не только положительные (в области драматургии зрелища), но и негативные (нарушение законов балетной специфики, потеря развитой танцевальности). Гармония сочетания сценарной и музыкально-хореографической драматургии возможна только
BALLET LIBRETTO AS A SUBJECT OF CONCEPTUAL ANALYSIS OF A CHOREOGRAPHIC WORK ION THE MATERIAL OF UKRAINIAN COMPOSERS' WORKSI

\author{
Oleksandr Chepalov \\ Doctor of Arts, Professor, \\ Kyiv National University of Cultural and Arts, \\ Kyiv, Ukraine, \\ https://orcid.org/0000-0002-2033-357X, \\ chepalovstagmail.com
}

The purpose of the article is to find out the regularities and means of practical creation of a ballet performance script from the standpoint of dramatic and musical-choreographic construction. The methodology is to combine the empirical method based on the practice of professional experience in creating ballet librettos with general scientific approaches, including analogy and modelling, abstraction and concretization, arising from the conceptual foundations of the principles of a figurative-artistic embodiment of stage work. Scientific novelty. In comparison with opera libretology the general theory and practice of ballet libretto are not developed; therefore, the proposed study is one of the first to claim theoretical generalizations and reproduce a more modern view of one of the urgent problems of creating a ballet performance in our time. Conclusions. In Soviet ballet, due to the tasks of ideology and content of the drama, the role of the script increased compared to the ballets of the past. However, the desire to bring the script closer to a dramatic play (especially a typical phenomenon for the 1930s and 1950s) yielded results not only positive (in the field of spectacle drama) but also negative (violation of the laws of ballet, loss of advanced dance). The harmony of the script and musical-choreographic drama combination is possible only in performances when the scripts are created taking into account the specifics of music and choreography and their organic fusion. Due to the expansion and enrichment of modern elements of expressive means of choreography, 
в спектаклях, в которых сценарии созданы с учетом специфики музыки и хореографии и их органического слияния. Благодаря расширению и обогащению современными элементами выразительных средств хореографии, балетные либретто становились не просто расширенным описанием сценических событий, а их более коротким и емким изложением, они давали широкий простор фантазии зрителя и когнитивного восприятия хореографического текста. Украинские художники ориентировались преимущественно на классические балетные образцы, обращаясь к отечественной и мировой литературной классики, сюжетов-легенд, произведений историко-патриотической тематики. Некоторые балеты создавались к общественно значимым событиям (напр., «Огонь Элиды» В. Золотухина к Олимпиаде 1980 в Москве). Балет В. Бибика в 2 действиях «Гуттаперчевый мальчик» написан по одноименной повести Д. Григоровича (сохранился только в клавире). Создание драматургии балетного спектакля требует значительно больших усилий, чем в опере; ее отличают от сценарной формы, апробированной в оперной спектакле, монологи, диалоги и прописанный (преимущественно в ремарках) подтекст.

Ключевые слова: балетное либретто; сценарная драматургия балета; балетная музыка украинских композиторов; композитор Владимир Золотухин; композитор Валентин Бибик. ballet librettos became not just an extended description of stage events but their shorter and more capacious presentation; they gave a wide space for the spectator's imagination and cognitive perception of the choreographic text. Ukrainian artistic creators focused mainly on classical ballet samples, turning to domestic and world literary classics, stories, legends, works of historical and patriotic themes. Some ballets were created for socially significant events, e. g. "Fire of Elida" by V. Zolotukhin before the 1980 Olympics in Moscow. V. Bibik's ballet in two acts “The Gutta-percha Boy" is based on the novel of the same name by D. Hryhorovych (preserved only in the clavier). Creating the drama of a ballet performance requires much more efforts than in opera; it is distinguished from the script form tested in the opera performance by monologues, dialogues and a subtext (mostly in remarks).

Keywords: ballet libretto; script dramaturgy of ballet; ballet music by Ukrainian composers; composer Volodymyr Zolotukhin; composer Valentyn Bibik.

Актуальність теми дослідження. Авторитетне радянське енциклопедичне видання «Балет» (1981) дуже коротко й побіжно торкалося актуального в балетному жанрі поняття «лібрето». Одне із трактувань цієї дефініції, на думку автора енциклопедичної статті В. Ванслова, рівнозначне поняттю «сценарій». Друге формулюється так: «викладення сюжету балету у програмці вистави, що допомагає глядачеві зрозуміти дію, яка відбувається на сцені» (Ванслов, 1981). У межах запропонованої статті нас буде цікавити насамперед сценарій балету, створеного автором літературного тексту в співдружності з балетмейстером та композитором. Лібрето для глядачів (якщо воно на сьогодні є єдиним джерелом та підсумком подібної співпраці) може допомогти в концептуальному аналізі твору, тобто достеменному розумінні ідей і творчих завдань його авторів.

Аналіз останніх досліджень. Теоретиками створення балетного лібрето були відомі митці й дослідники 1960 - 1980-х рр. - Р. Захаров з його відомим теоретичним та педагогічним доробком «Искусство балетмейстера» (1954), «Записки ба- 
летмейстера» (1976), «Сочинение танца» (1983); добре відомі праці історика балету й лібретиста Ю. Слонимського («Семь балетних историй» (Слонимский, 1967), «Драматургия балетного театра XIX века» (Слонимский, 1977) та мистецтвознавця В. Ванслова («Балеты Григоровича и проблемы хореографии» (1971), «Статьи о балете» (1980)). Фундаментальні й багатопрофільні роботи П. Карпа були зібрані в електронному двотомному виданні «Полвека с балетом» (Карп, 2018). У ньому можна знайти чимало слушних думок про специфіку балетного лібрето.

Порівняння старих зразків лібрето із сучасними легко зробити в процесі компаративного аналізу відповідних розробок Ж.-Ж. Новерра «Листи про танець та балети» (Новерр, 2007) та вже згаданого адепта драматичного балету Р. Захарова, який, подібно до Новерра, у своїй книзі «Сочинение танца» (1983) наводить приклади лібрето власних хореографічних вистав. Однак комплексного розгляду балетного лібрето як предмета концептуального аналізу хореографічного твору виявлено не було.

Мета статті - з'ясувати закономірності та засоби практичного створення сценарію балетної вистави з позицій драматичної та музично-хореографічної побудови.

Виклад основного матеріалу. У найбільш досконалих зразках балетного театру драматургія заснована на природній єдності сценарію, музики й хореографії. Це характерно для сценічних творів балетного жанру, починаючи з часів Ж.-Ж. Новерра. Проте поняття та зміст дефініції «лібрето» зазнавало багато змін у процесі еволюції балетної вистави. Особливо це позначилося на хореографічних творах XX ст., адже серед них траплялися безсюжетні вистави (в обмеженій кількості), балети-п'єси (драмбалети), особливо в СРСР, Великій Британії, Німеччині.

Р. Захаров пропонує відносно нове поняття: замість загальновизнаних «лібрето» та «сценарій» він застосовує дефініцію «програма», маючи на увазі змістовний та насичений перелік подій у їхній драматургічній послідовності. У сучасній ситуації, коли «лібрето» давно й беззаперечно належить оперному жанрові, а сценарій може відноситися до інших драматургічних творів (наприклад, проєкту масового свята або основи кінематографічного твору), використання слова «програма» стосовно балетної вистави взагалі не викликає принципових заперечень. Що ж до великої (в тому числі творчої) спадщини Ю. Слонимського як лібретиста та співавтора багатьох сучасних своїй епосі балетів, то він також виявився заручником радянської ідеології й визначених нею художніх табу. 3 початком нової балетної епохи Ю. Григоровича лібрето поставлених ним вистав (а за цим - його послідовників) почало позбавлятися пантомімно-побутової описовості й набувати тих образних характеристик, що відповідали новим принципам естетики симфонічного балету.

3 часом, завдяки розширенню та збагаченню сучасними елементами виражальних засобів хореографії, балетні лібрето ставали не просто описом сценічних подій, а їхнім більш коротким та ємним викладенням, вони давали широкий простір фантазії глядача та когнітивного сприйняття хореографічного тексту. Сценарії у XX ст. часто створювали балетні драматурги (наприклад, Ю. Слонимський, П. Аболімов, М. Волков, О. Белінський, а в Україні -Е. Яворський, Ю. Станішевський, М. Черкашина-Губаренко й ін.), але переважно авторами літературного сценарію або лібрето були самі балетмейстери, навіть такі, що не мали літературного хисту. Іноді, зважаючи на специфіку драмбалету (хореодрами) до балетмейстерів долучалися режисери: наприклад, у створенні балету «Ромео і Джульєтта» С. Прокоф’єва брав участь С. Радлов (друга половина 1930-х рр.), у більш сучас- 
ній виставі тієї ж назви та «Гамлеті» Р. Поклітару (початок XXI ст.) - британський режисер Д. Донелан. Усі спектаклі Ю. Григоровича, Н. Касаткіної і В. Васильова, Б. Ейфмана та багатьох інших відомих хореографів, поставлені за їхніми сценаріями, особливо якщо йдеться про власний задум та одноосібне втілення балету.

У радянському балеті у зв'язку із завданнями ідейності та змістовності драматургії роль сценарію підвищилася порівняно з балетами минулого. Проте прагнення наблизити сценарій до драматичної п'єси, особливо типове для 1930 1950-х pр., давало результати не лише позитивні (досягнення в галузі драматургіi), але й негативні (порушення законів балетної специфіки, втрата розвиненої танцювальності). Гармонія поєднання сценарної та музично-хореографічної драматургії можлива лише в спектаклях, де сценарії створені з урахуванням специфіки музики і хореографії та їхнього органічного злиття.

Сценарій (італ. scenario, від латин. scaena, scena - сцена) - словесний проєкт балетного спектаклю, що містить викладення його основних подій (сюжет), ідеї, конфлікту, характерів дійових осіб. Сценарій у певних випадках називають лібрето, насамперед за все, коли текст уже призначений для ознайомлення глядача з майбутнім видовищем і слугує допоміжним матеріалом для розуміння сценічних подій. На першому етапі сценарій слугує основою для створення балетної музики й постановки спектаклю. Тому він може містити детальні описи й пояснення дії, діалоги і внутрішні монологи, які допомагають творцям балету в роботі над спектаклем, але не входять у його художню тканину. Відсутність слова в балеті компенсується сценарними засобами, тобто постає у прихованому вигляді, втілюючись у музиці й хореографії (в тому числі в дієвому танці, специфічній балетній пантомімі тощо) (Ванслов, 1981).

Сценарій не лише складова частина хореографічного твору, але й особливий рід літератури. За допомогою сценарію здійснюється зв'язок балету з літературою; отже, основою сценарію можуть бути відомі літературні твори ("Бахчисарайський фонтан» за однойменною поемою О. Пушкіна, "Лісова пісня" за драмою Лесі Українки, "Маленький принц" за казкою А. Сент-Екзюпері та ін.).

Сценарій - специфічний вид драматургії з очевидною передпризначеністю для музично-хореографічного втілення. У зв'язку з особливостями балетного жанру він зазвичай будується на основі моделювання великих музично-хореографічних сцен, що втілюють вузлові, етапні моменти дії, його кульмінаційні події, оминаючи дрібні подробиці. Поза балетною виставою сценарій втрачає сенс, його самостійність відносна. Детальні словесні описи і характеристики можуть мати в сценарії лише допоміжне значення, для самого ж спектаклю визначальну роль грає ідея сценарію, внутрішня драматургія вчинків, стосунків і переживань людей. Якщо сценарій створений без урахування вимог музично-хореографічної дії, то в процесі роботи над постановкою він нерідко зазнає змін, пристосовуючись до специфічних умов симфонічної драматургії хореографічного твору та його стильових особливостей. Спробуємо цей процес відстежити у зворотному порядку, тобто відштовхнутися від початкового задуму створення балету та проаналізувати його кінцевий результат.

Автору цих рядків довелося особисто спілкуватися з багатьма харківськими композиторами, зокрема як лібретисту в процесі створення балетних творів з учнями знакового українського митця Дмитра Львовича Клебанова (1907-1987) Володимиром Максовичем Золотухіним (1936-2010) та Валентином Савичем Бібіком (1940-2003).

В. Золотухін був талановитим автором творів різних жанрів - від камерних до симфонічних, але спеціально написана балетна партитура «Вогонь Еліди» булаву 
нього одна (створений у 1996 р.симфонічний твір «Купальські ігри» використано пізніше для постановки однойменного балету на одну дію).

Балетна вистава «Вогонь Еліди» була підготовлена в радянські часи до проведення Олімпіади - 1980 на замовлення репертуарного комітету Міністерства культури УРСР. Згідно з ідеологічними канонами тієї доби на цю виставу накладався особливий, символічний смисл, адже XXII Олімпійські ігри 1980 р. у столиці СРСР мали оспівувати не тільки сталеві м'язи й стрімкі поривання до перемоги в олімпійських змаганнях, але й самі Ігри з їхнім мудрим і благородним принципом - здобувати звання найсильнішого без винищувальної зброї в руках. Уже в новітній історії Оду спорту проспівав у віршованій формі лідер та ідеолог Олімпійського руху П’єр де Кубертен (1863-1937).

Початковий задум «олімпійського» балету викристалізовувався поступово та ініціювався постановником - артистом балету Харківського академічного театру опери та балету ім. М. Лисенка В. Соболєвим, для якого ця самостійна робота була дипломною як для балетмейстера, випускника Московського державного інституту театрального мистецтва. Удвох ми почали розробляти сюжет і образи майбутнього балету. Асоціативно викристалізувався в уяві герой - мужній і сильний атлет, давній еллін, який мовою пластики й жесту повідав би про олімпійські події. Окрім героя, звичайно, мала бути й героїня, яка вписувалася б у тему переборення героєм певної антилюдяної сили та була б співзвучною сучасності. Відповідно кульмінацією спектаклю мав стати поєдинок між героєм та його суперником. Так був знайдений головний конфлікт спектаклю: атлет-олімпієць перемагає найпідступнішого із синів Зевса - Ареса. Отже, смисл поєдинку - Людина проти Бога війни. Цей конфлікт вимагав не тільки поетичного висловлення, але й конкретної психологічної мотивації героїв, дієвості їхніх вчинків.

Відомо, що правила давніх Олімпійських ігор проголошували: усі ворожі дії 3 моменту оголошення священного Місяця Ігор припиняються; той, хто зробить спробу напасти на цю територію чи не допоможе народові в разі нападу, буде підданий прокляттю богів.

Так, несподівано для авторів, у підході до теми поєдналися історично достовірні факти і метафоричність «божественного» начала. Після цього стало зрозумілим, що головною, єднальною із сучасністю, темою в балеті має бути організація Олімпійських ігор як спроба захистити народи від війни.

Історики вважають, що перші Олімпійські ігри відбулися в 776 р. до н. е. У той час Давня Греція складалася $з$ невеликих, роздрібнених держав - полісів, між якими точилися безперервні війни. Священне місце поклоніння Зевсу - Олімпія - знаходилася в Еліді, одній з областей Пелопонесу. I коли було оголошено довгоочікуване перемир'я, саме тут, в Еліді, було вирішено провести «атлетичні ігри, угодні богам». У такий спосіб були увіковічнені миролюбні прагнення греків, і з того часу раз на чотири роки разом з оголошенням чергової Олімпіади наставало перемир'я. 3 Еліди в усі кінці Греції направлялися гінці (теори) і своєю владою зупиняли війни. Було вирішено, що наш атлет на ймення Аріон стане саме таким теором, вісником перемир'я. Він понесе звістку про відкриття Олімпіади, але йому перепинить дорогу Бог війни, що миру, звісно, не бажає.

Спектакль дістав назву «Вогонь Еліди». Вважаючи найважливішим відтворити сучасні думки про значення і смисл Олімпіади, В. Золотухін використав переважно відповідні засоби виражальності, у тому числі властиві його музиці прийоми симфоджазу. 
Залишаючись вірним своїм теоретичним позиціям, композитор здійснив у балеті «стрибок» якісного характеру. Раніше він будував музичну драматургію на співставленні тем, коли в музиці почало відчуватися їхнє непримиренне протиборство. Стрімка, «політна» тема Аріонабула сповнена благородної відваги; вона утверджувала творчу місію людини на землі, її стійкість і вірність обов'язкові. Загрозливий, злісний характер Бога війни, був відчутним у музиці, i тематика Аріона вступали у протиборство, виливалися у великі симфонічні епізоди, надаючи балетові цільного, монументального вигляду, епічного розмаху.

Важливого значення в балеті В. Золотухін надавав і ліричним сторінкам партитури - ніжній, майже пасторальній музиці початку другої картини, «солоспіву» головної героїні балету Хілони, натхненному адажіо юних героїв.У балеті «було також кілька жанрових епізодів, де найбільшою мірою відчувалося бажання композитоpa і балетмейстера надати задумові не лише поетичної узагальненості сюжету, але й емоційної достовірності, з яскравою образністю розкрити багатство людських переживань, сенс вчинків дійових осіб і в музиці, і в танці» (Гусарова, 1988, с. 24).

Лібрето у свій спосіб перетворилось із допоміжного сценарного тексту на цілком художній твір, стилізований під гекзаметр:
«Было в Элладе раздробленных много владений.
Но среди них красотой поражала Элида.
Самые стройные тут возвышались платаны,
Самые сильные люди в Элиде рождались.
Здесь бы трудиться и здравствовать, горя не зная,
Землю возделывать, мудрость старейшин лелеять.
Но, подчиняясь законам бесчестным раздора,
Кровью сограждан за мир элидяне платили...».

(Золотухин, 1988, с. 4)

Через зміну тематичного матеріалу й темпоритму, фактури й усіх інших чинників музично-симфонічного розвитку поступово позначалися у «Вогні Еліди» й дійові колізії, кульмінаційні епізоди, етапні моменти розвитку сюжету. На їхньому чергуванні й побудовані дієві зміни - від зав'язки до розв'язки. У балетах старого зразка автори охоче використовували показ подробиць сюжету, опис побуту тощо, оскільки орієнтувалися на балет-п’єсу, підготовлену за усталеними правилами драматичної сцени. Проте це не є обов'язковим. У безсюжетному балеті (звичайно, тому, що народжений неокласикою) драматургія заснована на зіставленні та контрастах певних ідей (не обов’язково соціальних або політичних, швидше художньо-філософських, візуально-абстрагованих).

Відомий український мистецтвознавець, знаний фахівець у галузі балету Ю. Станішевський дав схвальний підсумковий відгук на прем’єру балету В. 3олотухіна, коли писав, що балетмейстер В. Соболєв створив емоційно-наснажену танцювальну дію, що відповідала яскраво-колористичній гамі декораційного рішення. Досить переконливо змалювали постановник і солісти образи персонажів (Станішевський, 2003, с. 233).

Балет «Гутаперчевий хлопчик» за мотивами однойменної повісті Д. Григоровича, лібрето якого я запропонував у 1986 р. В. Бібіку, був позначений 65 опусом, і залишився в його творчій спадщині лише в клавірі. В авторському виконанні на фортепіано був записаний на магнітну плівку. Перемовини щодо постановки 
3 кількома відомими балетмейстерами, на жаль, не дали практичного результату, бо, як сьогодні можна зрозуміти, музика балету «про нещасного хлопчика» (авторський підзаголовок на титульній сторінці) сприймалася занадто складною для дитячого балету, а фінал не мав традиційного оптимістичного завершення. Проте через 35 років після написання ця музика вже не вважається заважкою для сприйняття та може бути жанрово вирішена хореографами як мелодрама 3 відкритим фіналом, цілком відповідаючи смакам сімейного перегляду.

Балетне лібрето, як і твір письменника, починається з опису заметілі напередодні Святвечора. Це, власне, пролог до балету зі складними та багатозначними психологічними й філософськими передчуттями: «Зігріти серце в таку пору немає жодної можливості, - пише Григорович, -хіба що доля піднесе тобі якийсь подарунок і скаже: розпоряджайся ним, як захочеш. Подарунком долі може виявитися випадково упущена кимось думка або звуки музики, що доносяться з цирку-шапіто. Тут відбуваються омани дивовижні, але бажані - нас смішать сумні обличчя клоунів і заспокоюють посмішки, з якими акробати роблять свої небезпечнітрюки, і ми починаємо розуміти, що цирк у цьому зовсім недалекий від життя, а життя - од цирку, де майже невловима межа між сумним і смішним, святковим і буденним» (Григорович, 1988, с. 98).

Цей «заспів» під час виконання композитор супроводжував легким насвистуванням та глісандо по струнах фортепіано, що імітували завірюху. Далі крізь ці звуки «проривалися» інтонаційні сплески циркового оркестру, що вабилислух та немов насправді обіцяли стати справжнім святом душі.

Далі, за законами класичної драматургії, йшла експозиція головних героїв твору, які приваблюють увагу глядачів біля шапіто - Директора цирку та учасників параду-алле, а це були Жінка-змія, Силач, рудий Клоун та найбільш бажані глядачі на дорогі місця - Граф із маленькою донькою (за лібрето просто Дівчинка). Дівчинка - друга за значенням дійова особа балету. У своїх покоях, під наглядом Графа, вона відчуває себе немов у золотій клітці. Батько Дівчинки віддає перевагу не рухливим іграм з їхньою «безглуздою» метушнею, а салонним танцям, до яких звик з давніх пір. $€$ щось завчене, механічне в тому нудному уроці, який дає Граф дочці, і тому Дівчинка надзвичайно радіє першому виходу до цирку, де мріє побачити цікаві розваги й сміливі трюки.

Представлена ситуація добре відчувається у відповідному епізоді, який В. Бібік переконливо побудував у 2-й дії балету, використавши стилізацію салонних танців. Майже водночас і паралельно на арені відбувається репетиція виступу Гутаперчевого хлопчика, який, ставши сиротою, раптово потрапив до цирку; саме завдяки його неймовірним фізичним якостям, кожен з персонажів - циркачів мріє пристосувати його дар для своєї вигоди.

Композитор написав для картини репетиції дивовижне за формою та вражаючою силою скерцо, де оригінальна мелодична тема повторюється в настирливій послідовності та демонструє професійну муштру і професійну витривалість, без яких виступ Гутаперчевого хлопчика не може бути успішним. Проте внаслідок заздрісних інтриг люди з недобрим серцем пошкоджують крихку оболонку душі Хлопчика, тож цей «подарунок долі» не дістається жодному, навіть Дівчинці, яка в числі інших стала свідком фатального падіння Хлопчика 3-під купола цирку.

Наукова новизна. У порівнянні з оперною лібретологією загальна теорія й практика балетного лібрето не розроблена; отже, запропоноване дослідження є од- 
ним із перших, що претендує на теоретичні узагальнення та відтворює більш сучасний погляд на одну з нагальних проблем створення балетної вистави у наш час.

Висновки. У найбільш досконалих зразках балетного театру драматургія заснована на природній єдності сценарію, музики й хореографії. Це характерно для сценічних творів балетного жанру, починаючи з часів Ж.-Ж. Новерра. Проте поняття та зміст дефініції «лібрето» зазнавало багато змін у процесі еволюції балетної вистави. Особливо це позначилося на хореографічних творах XX ст., адже серед них траплялися безсюжетні вистави (в обмеженій кількості), балети-п'єси (драмбалети), особливо в СРСР, Великій Британії, Німеччині.

Українські митці, використовуючи кращий досвід колег із союзних республік (про передові досягнення західних хореографів до певного часу не йшлося), орієнтувалися переважно на класичні балетні зразки, звертаючись як до джерела натхнення до вітчизняної та світової літературної класики, сюжетів-легенд і творів історично-патріотичної тематики. Деякі балети ("Вогонь Еліди" В. Золотухіна) було написано до певних суспільно значущих подій (Олімпіада 1980 р. у Москві), проте він відбувся як повноцінне художнє явище. До того ж етимологія слова «вогонь» сприяла його багатоваріантному символічному використанню, а місце дії - священна область Еліда, де відбувалися Олімпійські ігри - визначало історичну сутність балету, прояснювало його жанр - легенда про виникнення олімпійського вогню. Отже, в основу балетної вистави було покладено сюжетний та смисловий конфлікт, що розвивався і мав емоційно-змістовне розрядження впродовж музично-хореографічної дії. Концептуальне завдання, що було поштовхом для написання балетного лібрето, виконувало не тільки ідеологічну функцію, а й надихало на створення художньо-мистецького зразка в жанрі хореографічного мистецтва.

Балет В. Бібіка на 2 дії «Гутаперчевий хлопчик» за повістю Д. Григоровича був створений (і зберігся тільки у клавірі) як спроба непересічного композитора долучитися до жанру музичного театру (пізніше це успішно було реалізовано ним в оперній партитурі «Біг» за М. Булгаковим). Відзначимо, що створення драматургії балетної вистави вимагає значно більших зусиль, ніж в опері, бо відрізняється від тієї сценарної форми, яка апробована у виставі оперній на підставі монологів, діалогів та прописаного (переважно в ремарках) підтексту.

Формами музично-сценічної драматургії, згідно із запропонованого композитору лібрето, став сольний танець (пластичні монологи Клоуна, Силача, Директора цирку, Жінки-змії), що могли б прислужити балетмейстерові для «портретних» характеристик. Передбачений був дуетний танець (наприклад, Графа з донькою), що виражає протиріччя їхніх намірів, ансамблевий танець гурту клоунів і танець-ексцентріада, контрастна за емоційним станом фатальному виступу Гутаперчевого хлопчика.

Зі змісту музики очевидно, що до хореографічної партитури балету В. Бібіка можуть бути включені також пантомімічні сцени, що не мають потреби чітко вираженої дансантності. В. Бібік вклав у музичний зміст твору поки незапитаний хореографами (балет досі не отримав сценічного рішення) меседж, що отриманий подарунок долі може залишитися нерозгаданим, отже, таким, що людина не змогла ним правильно розпорядитися. Автор літературного «Гутаперчевого хлопчика» Д. Григорович підкидає до нашої уваги й розгляду таку креативну для створення балету думку: звуки музики, що доносяться з цирку-шапіто спонукають до розуміння, що цирк зовсім недалекий від життя, а життя - від цирку, де майже невловима межа між сумним і смішним, святковим і буденним (Григорович, 1988, с. 91). 
Серед перспектив подальшого дослідження теми - створення балетної лібретології, у тому числі на прикладах співробітництва лібретистів та українських композиторів, що може сформуватися в монографічне дослідження.

\section{СПИСОК ПОСИЛАНЬ}

Ванслов, В. (1971). Балеты Григоровича и проблемы хореографии (2-е изд.). Искусство.

Ванслов, В. (1980). Статьи о балете: Музыкально-эстетические проблемы балета. Музыка.

Ванслов, В. (1981). Драматургия балета. В Ю. Григорович (Ред.), Балет: Энциклопедия (с. 53). Советская энциклопедия.

Григорович, Д. В. (1988). Сочинения в трёх томах (Т. 2). Художественная литература.

Гусарова, О. (1988). Володимир Золотухін. Музична Україна.

Захаров, Р. (1976). Записки балетмейстера. Искусство.

Захаров, Р. (1954). Искусство балетмейстера. Искусство.

Захаров, Р. (1983). Сочинение танца: Страницы педагогического опыта. Искусство.

Золотухин, В. (1980). Огонь Элиды: Балет-легенда в двух действиях [Буклет] (А. Чепалов, сост.). ХАТОБ.

Карп, П. (2018). Полвека с балетом (Т. 1-2). ЛЕМА.

Новерр, Ж. Ж. (2007). Письма о танце (2-е изд.; А. А. Гвоздев, пер.). Лань, Планета музыки.

Слонимский, Ю. (1967). Семь балетных историй. Искусство.

Слонимский, Ю. (1977). Драматургия балетного театра ХІХ века. Искусство.

Станішевський, Ю. (2003). Балетний театр України: 225 років історії. Музична Україна.

\section{REFERENCES}

Grigorovich, D. V. (1988). Sochineniya v Trekh Tomakh [Works in Three Volumes] (Vol. 2). Khudozhestvennaya literatura [in Russian].

Husarova, O. (1988). Volodymyr Zolotukhin. Muzychna Ukraina [in Ukrainian].

Karp, P. (2018). Polveka s Baletom [Half a Century with Ballet] (Vols. 1-2). LEMA [in Russian].

Noverre, J.-G. (2007). Pis'ma o Tantse [Dance Letters] (2nd ed.; A. A. Gvozdev, Trans.). Lan', Planeta muzyki [in Russian].

Slonimsky, Yu. (1967). Sem' Baletnykh Istorii [Seven Ballet Stories]. Iskusstvo [in Russian].

Slonimsky, Yu. (1977). Dramaturgiya Baletnogo Teatra XIX Veka [The Dramaturgy of the Ballet Theater of the 19th Century]. Iskusstvo [in Russian].

Stanishevskyi, Yu. (2003). Baletnyi Teatr Ukrainy: 225 Rokiv Istorii [Ballet Theater of Ukraine: 225 Years of History]. Muzychna Ukraina [in Ukrainian].

Vanslov, V. (1971). Balety Grigorovicha i Problemy Khoreografii [Grigorovich's Ballets and Problems of Choreography] (2 ${ }^{\text {nd }}$ ed.). Iskusstvo [in Russian].

Vanslov, V. (1980). Stat'i o Balete: Muzykal'no-Esteticheskie Problemy Baleta [Articles about Ballet: Musical and Aesthetic Problems of Ballet]. Muzyka [in Russian].

Vanslov, V. (1981). Dramaturgiya Baleta [Ballet Dramaturgy]. In Yu. Grigorovich (Ed.), Balet: Entsiklopediya [Ballet: Encyclopedia] (p. 53). Sovetskaya entsiklopediya [in Russian].

Zakharov, R. (1954). Iskusstvo Baletmeistera [The Art of the Choreographer]. Iskusstvo [in Russian].

Zakharov, R. (1976). Zapiski Baletmeistera [Choreographer's Notes]. Iskusstvo [in Russian].

Zakharov, R. (1983). Sochinenie Tantsa: Stranitsy Pedagogicheskogo Opyta [Composing a Dance: Pages of Pedagogical Experience]. Iskusstvo [in Russian].

Zolotukhin, V. (1980). Ogon' Elidy: Balet-Legenda v Dvukh Deistviyakh [Fire of Elis: A Legendary Ballet in Two Acts] [Booklet] (A. Chepalov, Comp.). HATOB [in Russian]. 